\title{
Rancang Bangun Otomasi Penguncian Pintu Rumah dan Saklar Lampu dengan Android Berbasis Arduino Uno
}

\author{
Fadli Dana Septiawan ${ }^{\star 1}$, Endah Sudarmilah ${ }^{2}$ \\ 1,2Program Studi Informatika, Universitas Muhammadiyah Surakarta \\ e-mail: fadlidana21@gmail.com*
}

\begin{abstract}
The development of technology that is very fast in this day and age makes many people use it to facilitate their work. Over time, security and automatic lamp replacement have become efficient requirements to be applied in the current era. For security itself is needed because safety or crime has become a social problem that makes all citizens uneasy, because crime rates continue to increase every year. The most common crime is theft at home. Meanwhile, to switch lights are needed to facilitate the lights without having to go directly with the switch. The system commonly used for these problems still uses manuals. This research aims to make a security system and this light switch based on Arduino. The design of security systems and automatic lamp switching uses an experimental method that is research that collects data based on direct recording. The results obtained from this system are the added security and effectiveness of using the light switch. The test uses Arduino as a remote controller and is received by Arduino via Bluetooth HC-05. This security system and automatic light switch integrate smartphone with Arduino.
\end{abstract}

Keyword: Android; Arduino; Automatic Switch; Alarm

\begin{abstract}
Abstrak
Perkembangan teknologi yang sangat pesat di era sekarang membuat banyak orang menggunakannya untuk mempermudah pekerjaannya. Seiring berjalannya waktu, keamanan dan saklar lampu otomatis menjadi kebutuhan yang efisien untuk diterapkan pada era saat ini. Untuk keamanan itu sendiri dibutuhkan karena kejahatan atau kriminalitas sudah menjadi permasalahan sosial yang membuat semua warga menjadi resah, karena tingkat kriminalitas yang terus meningkat setiap tahunnya. Kejahatan yang banyak terjadi adalah kasus pencurian dirumah. Sedangkan untuk saklar lampu dibutuhkan untuk mempermudah menyalakan lampu tanpa harus berinteraksi langsung dengan saklar. Sistem yang biasa digunakan untuk permasalahan tersebut masih menggunakan manual. Penilitian ini bertujuan untuk membuat sistem keamanan dan saklar lampu ini berbasis Arduino. Perancangan system keamanan dan saklar lampu otomatis ini menggunakan metode eksperimental yaitu penelitian yang pengumpulan datanya berdasarkan pencatatan lansung. Hasil yang didapat dari sistem ini adalah keamanan tambahan dan keefektifan penggunaan saklar lampu. Pengujian menggunakan Arduino sebagai pengendali jarak jauh dan diterima oleh Arduino melalui Bluetooth HC-05. Sistem keamanan dan saklar lampu otomatis ini berintegrasi antara Smartphone dengan Arduino.
\end{abstract}

Kata kunci: Android; Arduino; Saklar Otomatis; Alarm

\section{Pendahuluan}

Perkembangan teknologi yang sangat pesat saat ini membuat banyak orang menggunakannya untuk mempermudah pekerjaannya. Hal tersebut membuat Developer saling bersaing untuk mengembangkan rancangan bangun teknologinya. Berbagai macam teknologi telah muncul pada era saat ini. Sehingga, banyak bermunculan teknologi-teknologi mutakhir yang dapat mempermudah pekerjaan para penggunanya. Maka dari itu teknologi terbaik yang banyak dicari oleh kebanyakan pengguna dan juga memiliki kisaran harga yang dapat dijangkau.

Seiring berjalannya waktu, keamanan dan saklar lampu otomatis menjadi kebutuhan yang efisien untuk diterapkan pada era saat ini. Untuk keamanan itu sendiri dibutuhkan.karena kejahatan atau kriminalitas sudah menjadi permasalahan sosial.yang membuat semua 
warga.menjadi resah, karena tingkat kriminalitas yang terus.meningkat setiap tahunnya [1]. Kejahatan.yang banyak terjadi.adalah kasus pencurian dirumah. Sedangkan untuk.saklar lampu dibutuhkan untuk mempermudah.menyalakan lampu tanpa.harus berinteraksi langsung dengan saklar.

REPUBLIKA.CO.ID, JAKARTA -- Kasus pencurian menempati posisi teratas dalam daftar tindak kriminal yang sering terjadi di Jabodetabek selama 2014. Karenanya, Polda Metro Jaya meminta masyarakat lebih waspada menjaga harta dan jiwanya. Direktur Reserse Kriminal Umum Polda Metro Jaya, Komisaris Besar Polisi Heru Pranoto, mengatakan, yang paling utama masyarakat harus mewaspadai kasus pencurian. Tiga kasus pencurian masih dalam angka yang tinggi, di antaranya pencurian dengan kekerasan, pencurian dengan pemberatan, dan pencurian kendaraan bermotor [2].

Berdasarkan uraian latar belakang, maka.diperlukan adanya.variasi guna meningkatan sistem.keamanan dan kefektifan.dirumah. Salah satu sistem keamanan.yang dapat diterapkan adalah.sistem keamanan.otomatis dan saklar otomatis. Sistem ini.adalah penggabungan antara hardware dan software yang diaplikasikan pada rumah tersebut. sistem keamanan ini menggunakan arduino uno sebagai mikrocontroller, android sebagai sistem operasi dan bluetooth sebagai media transmisi.

Arduino uno merupakan sebuah sistem atau perangkat fisik dengan menggunakan software dan hardware yang sifatnya interaktif yaitu dapat menerima rangsangan dari lingkungan dan merespon balik [3].

MIT App Inventor adalah aplikasi inovatif yang dikembangan google dan MIT untuk mengenalkan dan mengembangkan pemrograman android dengan mentrasformasikan bahasa pemrograman yang kompleks berbasis teks menjadi berbasis visual (drag and drop) berbentuk blok-blok [4].

Berdasarkan.permasalahan tersebut, maka penulis membuat inovasi sistem keamanan otomatis dan saklar lampu otomatis dengan menggunakan android sebagai pengendali arduino uno dari jarak jauh yang telah diimplementasikan pada sebuah.rumah. Dalam hal ini dimaksudkan untuk menambah sistem keamanan dan kefektifan dirumah tersebut.

\section{Metode Penelitian}

Perancangan sistem ini menggunkan metode eksperimental, yaitu metode penelitian yang digunakan untuk mencari pengaruh perlakuan tertentu terhadap yang lain dalam kondisi yang terkendalikan [5]. Data penelitian ini diambil dari hasil percobaan mikrokontroler arduino uno yang menggunkan bluetooth sebagai penghubung dengan android untuk akses penguncian otomatis dan saklar lampu otomatis. Pengumpulan data juga dilakukan dengan perhitungan jarak untuk mengetahui berapa jauh jangkauan yang dapat di jangkau oleh bluetooth itu sendiri. Rancang bangun sistem ini memerlukan beberapa tahapan seperti yang ditunjukkan pada gambar 1.

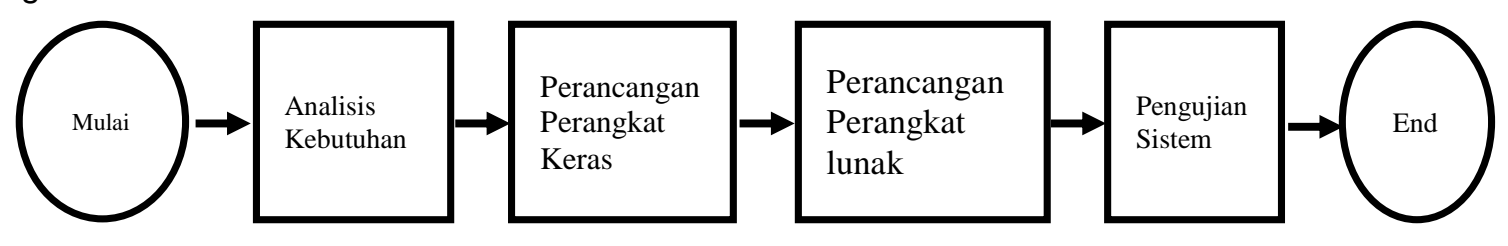

Gambar 1. Alur pembuatan sistem

\subsection{Analisis Kebutuhan}

Tahapan.pertama dalam analisis ini adalah kebutuhan.yang dibutuhkan.dalam perancangan sistem keamanan dan saklar lampu otomatis yang meliputi kebutuhan perangkat.keras dan kebutuhan perangkat lunak yang dibutuhkan.

\subsubsection{Kebutuhan Hardware}

Ada beberapa perangkat keras yang wajib ada pada penelitian ini. Hardware yang dibutuhkan adalah sebagai berikut:

a. Pada pembuatan aplikasi maupun desain menggunakan laptop dengan sepesifikasi sebagai berikut :

1. HP Pavilion Core i3 $1,80 \mathrm{Ghz}$

2. RAM 2 GB 
3. HDD $500 \mathrm{~GB}$

4. Mouse dan keyboard

b. Arduino Uno

Perangakat keras yang memiliki IC AVR328 yang bisa diprogram

c. Bluetooth $\mathrm{HC}-05$

Sebagai jembatan penghubung antara smartphone android dengan microkontroller arduino uno.

d. Kabel.

Sebagai penghubunga antara modul maupun sumber daya.

e. Selonoid elektrik

Untuk mengunci pintu dengan mengaliri arus dc pada modul.

f. Magnetik switch

Monitoring sebuah pintu apakah keadaan terbuka atau tertutup.

g. Buzzer

Berfungsi sebagai notifikasi berupa bunyi beep.

\subsubsection{Kebutuhan Software}

Penelitian kali ini membutuhkan sebuah perangkat lunak yang harus dipenuhi, software tersebut adalah:

a. Operating System

Pada penelitian ini sistem operasi yang akan digunkan adalah Windows 10 .

b. Software Arduino Uno

Aplikasi ini berfungsi sebagai pemberi program instruksi pada Arduino Uno.

c. App inventor

Aplikasi pembuat Android.

d. Fritzing

Untuk membuat sketsa rangkaian.

\subsection{Perancangan Perangkat Keras}

Tahap ini yaitu perancangan perangkat keras, penulis menggunakan arduino uno sebagai mikrocontroller dan komponen lainya yang telah diaplikasikan pada sebuah pintu dan lampu. Sketsa rangkaiannya dapat dilihat pada gambar 2 . Sedangkan sketsa gambaran umum sistem dapat dilihat pada gambar 3 .

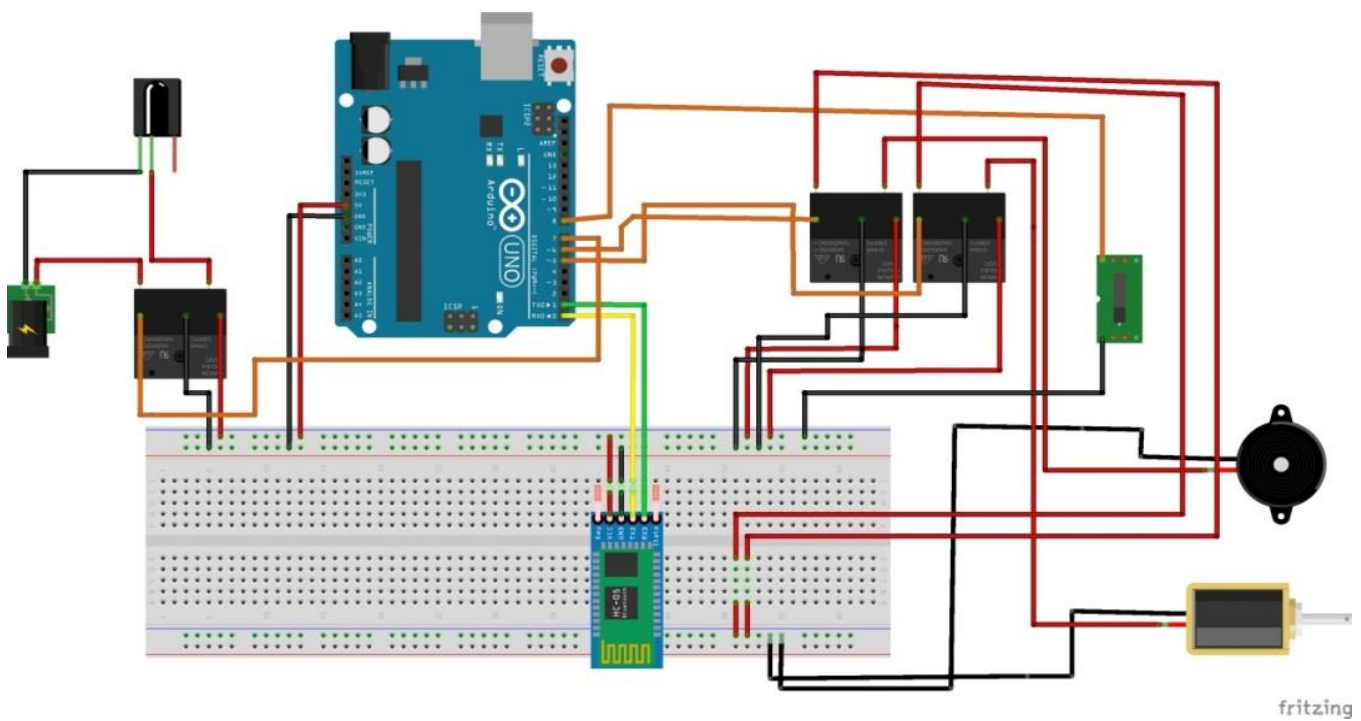

Gambar 2. Sketsa rangkaian keseluruhan perangkat keras

Berikut penjelasan tentang bagian dari sistem kendali android pada sketsa diatas:

a. Arduio Uno

Arduino uno ini sebagai pusat pengendali dari modul modul yang telah dipasang. Mikrokontroller akan menerima instruksi dari android yang akan dieksekusi oleh IC AVR 328. 
b. Relay

Modul ini berfungsi sebagai sklar. Cara kerjanya yaitu apabila dialiri arus maka relay akan aktif, dan apabila arus diputus maka relay akan tidak aktif.

c. Magnetic Switch

Rangkaian ini berfungsi sebagai sensor yang di pasang pada pintu. Sensor ini berfungsi sebagai notifikasi apabila pintu terbuka dan tertutup.

d. Beardboard

Digunakan untuk membuat rangkaian elektronik tanpa harus menggunakan solder.

e. Bluetooth

Bluetooth adalah perangakat peantara untuk menghubungkan antara smart phone dengan Mikrokontroler.

f. Buzzer

Bagian ini berfungsi untuk sebagai peringatan bunyi apabila pintu tidak dibuka dengan prosedur.

g. Solenoid

Fungsi modul ini adalah sebagai pengunci pintu. Di dalam modul ini terdapat magnet yang akan aktif apabila dialiri arus dan akan mengunci. Dan apabila arus diputus maka magnet dalam modul ini akan kehilangan medan magnet dan kunci tidak aktif.

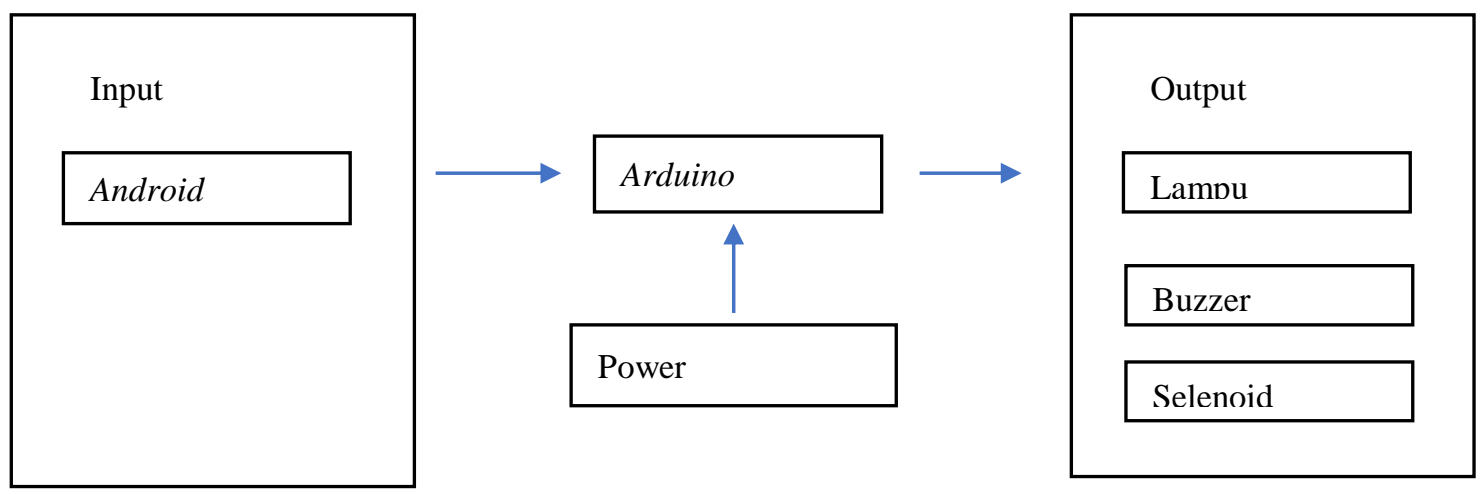

Gambar 3. Gambaran umum sistem

Gambar 3 menunjukkan alur cara kerja sistem yang akan dirancang. Pada gambar terlihat bahwa smartphone android akan mengirim instruksi pada rumah untuk melakukan penguncian, pembukaan dan menghidupkan lampu. Setelah pemilik rumah mengaktifkan salah satu intruksi tersebut, secara otomatis sensor akan aktif dan akan menghasilkan output seperti gambar diatas.

\subsection{Perancangan Perangkat Lunak}

Tahap berikutnya adalah perancangan perangkat lunak. Pada tahap ini terdapat dua perancangan yaitu perancangan UI dan perancangan arduino IDE. Perancangan UI dengan menggunakan MIT App Inventor yang diaplikasikan pada android yang dirancang sebagai pengirim data menuju mikrocontroler [6]. Flowchart dari perancangan UI dapat dilihat pada gambar 4 dimana smartphone akan terkoneksi dengan arduino melalui bluetooth kemudian smartphone akan mengirimkan perintah ke arduino dan akan langsung menjalankan sesuai perintah yang dikirimkan. Blok kode dari MIT App Inventor dapat dilihat pada gambar 5 dimana blok kode ini merupakan perintah yang sudah tersimpan di dalam program. Perancangan perintah logika pada Arduino ini dimaksudkan untuk dapat menerima dan mengolah data yang telah dikirim oleh Android yang telah terinstall aplikasi atau UI melalui media transmisi bluetooth. 


.

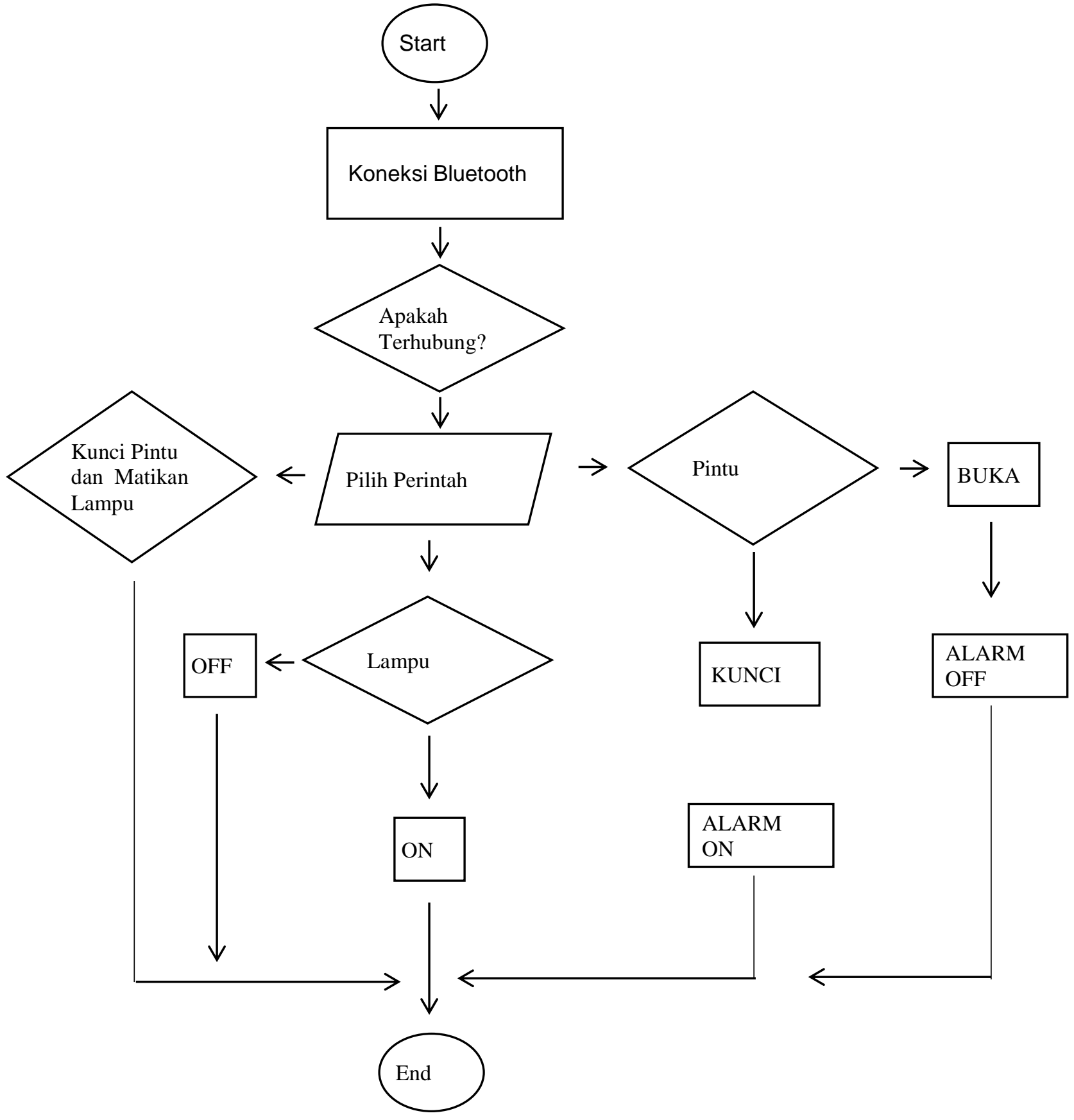

Gambar 4. Flowchart User Interface 


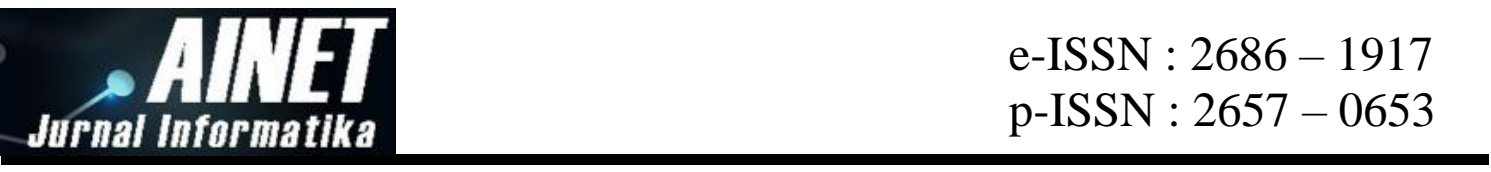
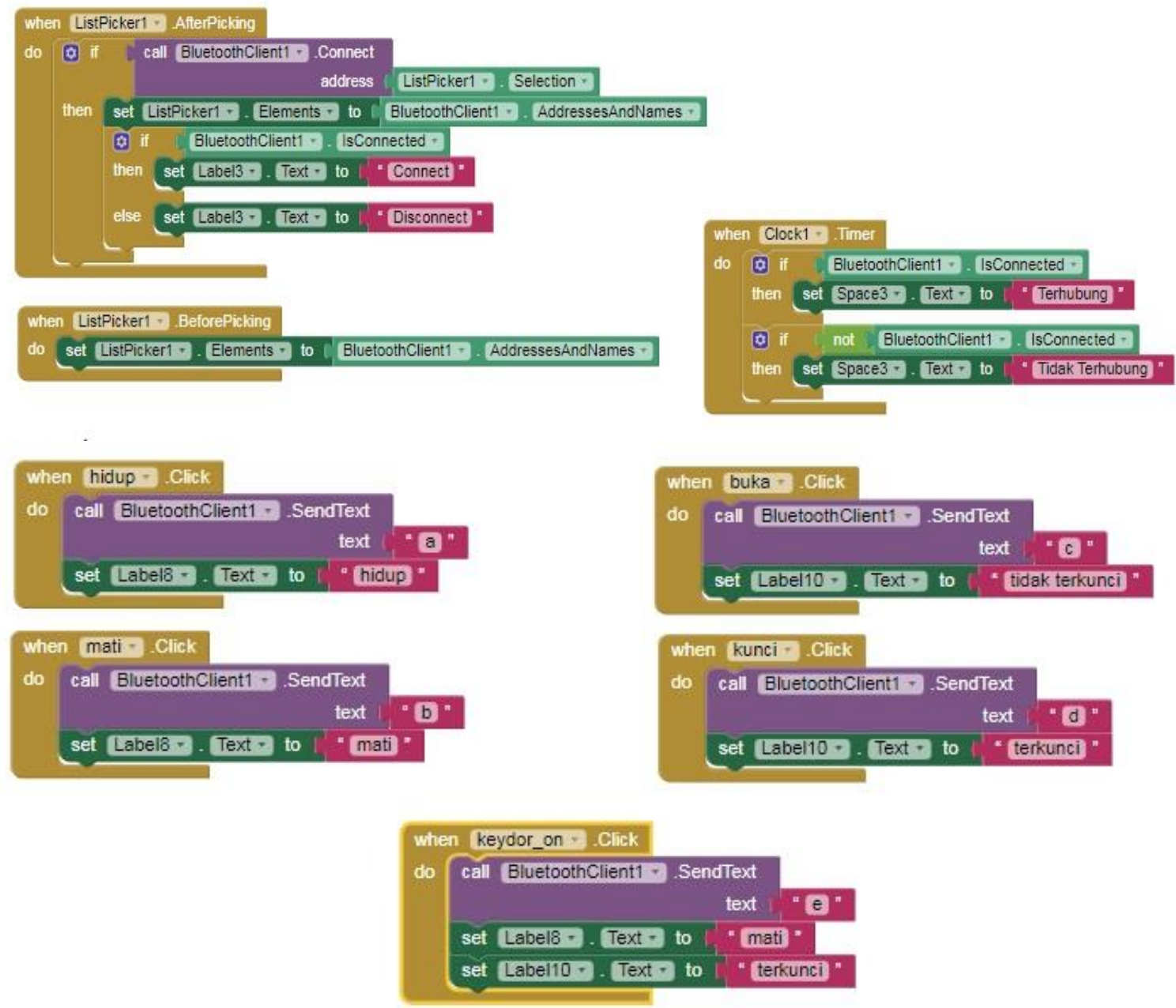

Gambar 5. Block kode app inventor

\subsection{Pengujian Sistem}

Tahap terakhir dalam perancangan sistem ini adalah pengujian baik perangkat lunak maupun perangkat keras, untuk mengetahui apakah sistem sudah sesuai dengan diagram alur yang dibuat. Pengujian pada perangkat keras ini meliputi ada kendala atau tidaknya komunikasi antara android dengan modul-modul lainnya. Sedangkan untuk perangkat lunak pengujian menggunakan arduino IDE untuk melihat apakah terdapat kesalahan atau tidaknya pada sistem tersebut.

\section{Hasil dan diskusi}

\subsection{Instalasi dan Konfigurasi}

UI dari sistem ini dibuat dengan menggunakan MIT App Inventor, sedangkan pembuatan kode program pada arduino menggunakan arduino IDE. Tampilan aplikasi yang telah dibuat dapat dilihat pada gambar 6 . Pada tampilan ini user diminta untuk menyambungkan bluetooth. 


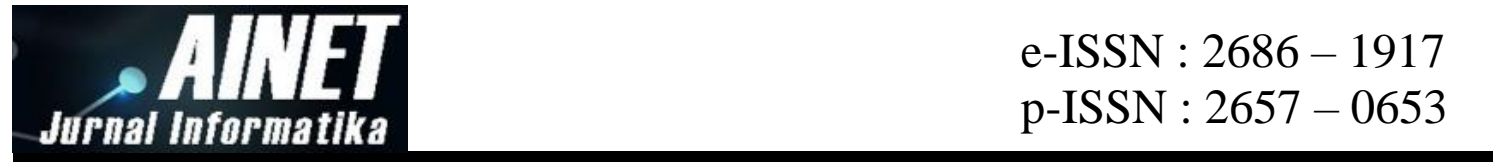

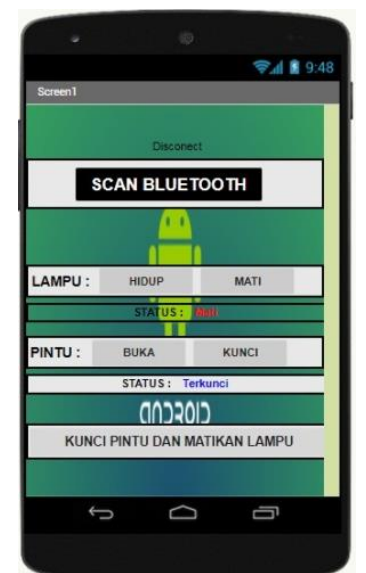

Gambar 6. Tampilan UI pada sistem ini

Sedangkan untuk system embedded, dimulai dari perakitan arduino, bluetooth HC-05, relay, solenoid, lampu, dan magnetik switch. Setelah selesai dirakit, rangkaian tersebut di implementasikan di pintu dan lampu. Rangkaian system embedded dapat dilihat pada gambar 7.

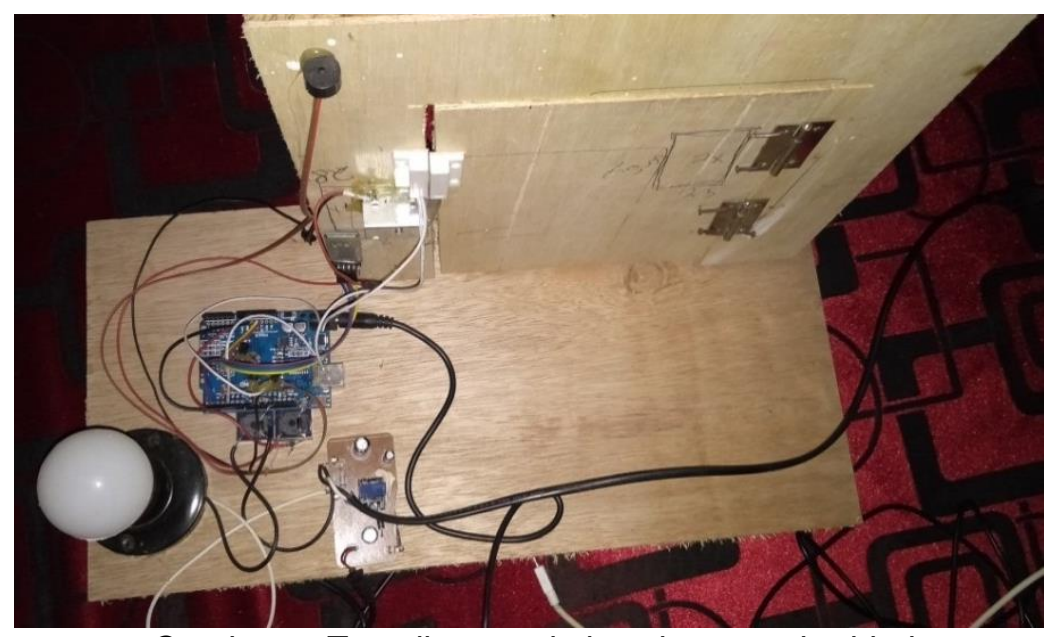

Gambar 7. Tampilan rangkaian sistem embedded

\subsection{Pengujian menggunakan Blackbox}

Pengujian blackbox adalah pengujian yang dilakukan untuk mengevaluasi pemenuhan sistem atau komponen dengan kebutuhan tertentu [7]. Pengujian ini dimaksudkan untuk mengetahui apakah fungsi-fungsi, masukan (input), dan keluaran (output) sesuai dengan spesifikasi yang di butuhkan. Berikut adalah hasil pengujian blackbox:

Tabel 1. Hasil pengujian blackbox

\begin{tabular}{|c|c|c|c|c|}
\hline No & Kasus Uji & $\begin{array}{l}\text { Output yang } \\
\text { Diharapkan }\end{array}$ & Output & Hasil \\
\hline 1. & $\begin{array}{l}\text { Penginstalan } \\
\text { Aplikasi }\end{array}$ & $\begin{array}{l}\text { Penginstalan dapat } \\
\text { dilakukan pada } \\
\text { smartphone Android } \\
\text { dan tidak ada pesan } \\
\text { error saat } \\
\text { melakukan } \\
\text { pemasangan } \\
\text { aplikasi. }\end{array}$ & $\begin{array}{l}\text { Penginstalan dapat } \\
\text { dilakukan pada } \\
\text { smartphone Android } \\
\text { tanpa pesan error. }\end{array}$ & Sukses \\
\hline 2 & Pairing Bluetooth & $\begin{array}{l}\text { Dapat melakukan } \\
\text { pairing atau } \\
\text { pemasangan }\end{array}$ & $\begin{array}{l}\text { Dapat melakukan } \\
\text { pairing Bluetooth } \\
\text { dengan lancar. }\end{array}$ & Sukses \\
\hline
\end{tabular}


perangkat Bluetooth

dengan benar.

3 Pengujian

Dapat mengirim

Pintu terkunci

Sukses

tombol kunci perintah kunci pada

pada arduino uno dengan

Android

menekan tombol

kunci ,akan secara

otomatis melakukan

penguncian pada

pintu

4. Pengujian tombol Dapat mengirim

buka pada perintah buka kunci

Android pada arduino uno.

Dengan menekan

tombol buka , maka

akan secara

otomatis melakukan

pembukaan kunci

pada pintu.

5. Pengujian tombol Dapat mengirim

Hidup pada perintah pengaktifan

Lampu Hidup

Sukses

Android

Lampu pada

mikrokontroller

Arduino Uno.

6. Pengujian tombol Dapat mengirim

Mati pada

Android

perintah matikan

lampu pada

mikrokontroller

Arduino Uno.

7. Pengujian tombol Dapat mengirimkan kunci pintu dan matikan lampu

dua perintah

sekaligus yaitu

Pintu terbuka

sukses

matikan lampu dan

kunci pintu

\subsection{Pengujian Perangkat Keras (Hardware)}

Pengujian hardware dilakukan dengan pengujian lapangan, yaitu dengan melakukan test langsung pada aplikasi android saat mengirimkan perintah kepada mikrokontroller maupun pada sensor yang akan digunakan pada penelitian ini [8].

\subsection{Pengujian dan Hasil terhadap Jarak Transmisi Bluetooth}

Pengujian transmisi bluetooth ini dilakukan dengan cara melakukan pada tempat terbuka yang dapat dilihat pada tabel 2 dan tempat yang disekeliling banyak benda disekitar alat dapat dilihat pada tabel 3. Pengujian ini menghasilkan data jarak yang akurat pada modul bluetooth yang digunakan sebagai penghubung antara android dan mikrokontroller.

a. Pengujian bluetooth pada ruang kosong

Tabel 2. Pengujian bluetooth pada ruang kosong

\begin{tabular}{ccc}
\hline Jarak & Hasil & Waktu Eksekusi \\
\hline 1 meter & Sukses & 0.4 \\
2 meter & Sukses & 0.4 \\
3 meter & Sukses & 0.5 \\
4 meter & Sukses & 0.5 \\
5 meter & Sukses & 0.5 \\
6 meter & Sukses & 0.6 \\
7 meter & Sukses & 0.6 \\
8 meter & Sukses & 0.7 \\
9 meter & Sukses & 0.7 \\
10 meter & Sukses & 0.7 \\
\hline
\end{tabular}




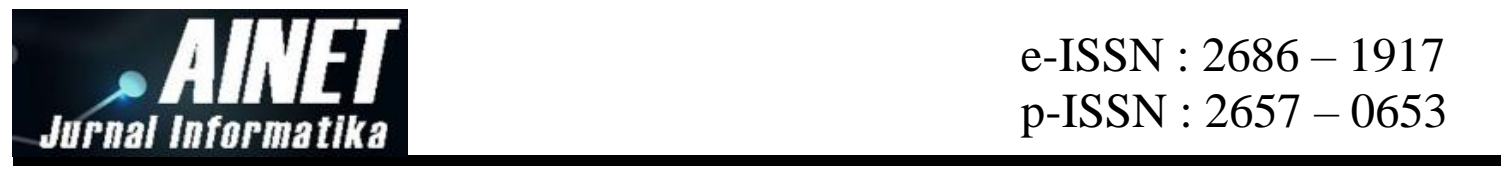

b. Pengujian bluetooth pada ruang tertutup (banyak benda di sekitar alat)

Tabel 3. hasil pengujian Bluetooth pada ruang tertutup

\begin{tabular}{ccc}
\hline Jarak & Hasil & Waktu Eksekusi \\
\hline 1 meter & Sukses & 0.4 \\
2 meter & Sukses & 0.4 \\
3 meter & Sukses & 0.5 \\
4 meter & Sukses & 0.5 \\
5 meter & Sukses & 0.5 \\
6 meter & Sukses & 0.6 \\
7 meter & Sukses & 0.7 \\
8 meter & Gagal & 0 \\
9 meter & Gagal & 0 \\
10 meter & Gagal & 0 \\
\hline
\end{tabular}

Pengujian jarak transmiter bluetooth maka dapat disimpulkan bahwa pada ruangan terbuka bluetooth dapat bekerja secara optimal maksimal dijarak 10 meter (Tabel 2), sedangkan diruang tertutup benda sangat mempengaruhi kinerja dari tansmisi bluetooth yang hanya optimal maksimal dijarak 7 meter (Tabel 3).

\section{Kesimpulan}

Berdasarkan dari hasil perancangan dan analisis penelitan yang sudah dilakukan, maka pada penelitian ini dapat diambil kesimpulan antara lain dari pengujian Black Box mempunyai presentase keberhasilan 100\% sedangkan pengujian langsung melalui bluetooth mempunyai 2 tipe yang berbeda yaitu diruang terbuka dan tertutup. Diruang terbuka keberhasil yang diperoleh sebesar $100 \%$ dalam jarak maksimal $10 \mathrm{~m}$ dan setiap percobaan ada perbedaan waktu setiap meternya, sedangkan diruang tertutup mempunyai presentase keberhasilan $70 \%$ dan mempunyai presentase kegagalan 30\%. Keberhasilan di ruang tertutup maksimal $7 \mathrm{~m}$. Berdasarkan kesimpulan tersebut penggunaan bluetooth sebagai media konektivitas kurang efektif untuk ruangan yang berukuran besar.

\section{Referensi}

[1] P. Dedi, "Angka Kriminalitas Naik, Polri Fokus Empat Kasus Kejahatan," CNN Indonesia, 2019. [Online]. Available: https://www.cnnindonesia.com/nasional/20190517062637-12395609/angka-kriminalitas-naik-polri-fokus-empat-kasus-kejahatan.

[2] P. Heru, "Kasus pencurian menempati posisi teratas dalam daftar tindak kriminal yang sering terjadi di Jabodetabek selama 2014," republika, 2014. [Online]. Available: https://www.republika.co.id/berita/nasional/jabodetabek-nasional/15/01/15/ni7sc7pencurian-dominasi-kasus-kejahatan-di-jabodetabek.

[3] D. F., "Pengenalan Arduino," 2011. [Online]. Available: http://www.tobuku.com/docs/Arduino-Pengenalan.pdf.

[4] E. S. Wihidayat, "Pengembangan Aplikasi Android Menggunakan Integrated Development Environment (Ide) App Inventor-2," Edutic-Scientific J. Informatics Educ., vol. 4, no. 1, 2017.

[5] N. Soekidjo, Metodologi Penelitian Kesehatan. Jakarta: Rineka Cipta, 2010.

[6] K. Abdul, Pemprograman Arduino dan Android menggunakan App Inventor. Jakarta: PT. Elex Media Komputindo, 2017.

[7] Zulkarnaen, "Metode Pengujian Perangkat Lunak," Stmik Bandung Bali, 2015.

[8] M. W. Sari and H. Hardyanto, "Implementasi Aplikasi Monitoring Pengendalian Pintu Gerbang Rumah Menggunakan App Inventor Berbasis Android," J. Eksplor. Karya Sist. Inf. dan Sains, vol. 9, no. 1, 2016. 